\title{
Quick method for identifying horse (Equus caballus) and donkey (Equus asinus) hybrids
}

\author{
M.M. Franco ${ }^{1,2,3}$, J.B.F. Santos ${ }^{2}$, A.S. Mendonça ${ }^{3}$, T.C.F. Silva ${ }^{2}$, \\ R.C. Antunes ${ }^{2}$ and E.O. Melo ${ }^{1}$ \\ ${ }^{1}$ Laboratório de Reprodução Animal, \\ Embrapa Recursos Genéticos e Biotecnologia, Brasília, DF, Brasil \\ ${ }^{2}$ Faculdade de Medicina Veterinária, Universidade Federal de Uberlândia, \\ Uberlândia, MG, Brasil \\ ${ }^{3}$ Instituto de Genética e Bioquímica, Universidade Federal de Uberlândia, \\ Uberlândia, MG, Brasil \\ Corresponding author: M.M. Franco \\ E-mail: mauricio.franco@embrapa.br
}

Genet. Mol. Res. 15 (3): gmr.15038895

Received June 16, 2016

Accepted July 26, 2016

Published September 23, 2016

DOI http://dx.doi.org/10.4238/gmr.15038895

Copyright $(\mathcal{C} 2016$ The Authors. This is an open-access article distributed under the terms of the Creative Commons Attribution ShareAlike (CC BY-SA) 4.0 License

\begin{abstract}
The domestication of the Equus genus 5000-6000 years ago has influenced the history of human civilization. As soon as horse and donkey species had been domesticated, they were crossbred, producing humanity's first documented attempt at animal genome manipulation. Since then, the mule (male donkey x female horse) and the reciprocal cross (the hinny, male horse $\mathrm{x}$ female donkey) have been the most common equine hybrids in the world. Due to their hybrid vigor, mules and hinnies have been intensively used for carrying loads and people and for tilling the land. Despite their importance, visual
\end{abstract}


distinction of mules and hinnies is difficult due to high phenotypic resemblance. However, the distinction between these two hybrids is of pivotal importance for equid breeders and ranchers. In this study, an easy, low-cost, effective, and fast multiplex-polymerase chain reaction method was developed to distinguish the maternal origin of mules and hinnies, targeting the hyper-variable mitochondrial DNA D-loop region. This methodology can help breeders, ranchers, animal science professionals, and researchers manage their equine herds with more confidence and precision.

Key words: Genotyping; Hinny; Mule; Multiplex-PCR

\section{INTRODUCTION}

The exact date and details of the domestication of the horse (Equus caballus; $2 \mathrm{n}=$ 64) are uncertain, but recent DNA analyses suggest multiple-domestication events around 5000 years ago (Jansen et al., 2002). The domestication of the donkey (E. asinus; $2 \mathrm{n}=62$ ) probably occurred around 6000 years ago in North Africa (Egypt area) from the Nubian and Somalian ass (E. a. africanus and E. a. somaliensis) (Beja-Pereira et al., 2004; Rossel et al., 2008). As soon as these two species from the Equus genus had been domesticated, they were crossbred, producing humanity's first documented attempt at genome manipulation around 5000 years ago (Allen and Short, 1997; Short, 1997). Since then, the mule (male donkey x female horse) and the reciprocal cross, the hinny (male horse $\mathrm{x}$ female donkey) have been the most common equine hybrids, due to the worldwide success and dissemination of horse and donkey domestication (Allen and Short, 1997). The mule and hinny are sterile hybrids $(2 n=$ 63), because their chromosome imbalance provokes a chromosomal disruption during meiosis (Allen and Short, 1997; Short, 1997). However, there are documented scientific reports of fertile mules (Ryder et al., 1985; Rong et al., 1988). Due to their hybrid vigor, the mule and hinny have been used worldwide for carrying loads and people, and for tilling the land from the ancient civilizations of Egypt, Mesopotamia, China, and the Roman Empire. They have, indeed, become essential to human culture and development (Short, 1975, 1997; ArangurenMéndez et al., 2002; Rossel et al., 2008; Chen et al., 2010). In addition, due to their vigor and intelligence, mules and hinnies are widely used in the management of cattle in large beef cattle ranches in Brazil, which are important to the regional economy.

Despite their importance in human civilization, the visual distinction of mules and hinnies is not easy (Figure 1), even for animal-breeding specialists, due to their phenotypic resemblance (Benirschke et al., 1964; Zhao et al., 2005). The distinction between these two hybrids is of pivotal importance for equid breeders, ranchers, and associations that keep the official pedigree of these animals.

Mammalian mitochondrial DNA (mtDNA) has a rate of nucleotide substitution one order of magnitude higher than nuclear DNA (Brown et al., 1979). mtDNA has been extensively employed in phylogenetic and evolution studies in mammals (Kim et al., 1999; Ivankovic et al., 2002; Cothran et al., 2005; Kakoi et al., 2007; Bower et al., 2013). More specifically, the noncoding mtDNA D-loop region is one of the most frequently employed DNA regions in phylogenetic studies. This is due to its fast rate of evolution, with a substitution rate five

Genetics and Molecular Research 15 (3): gmr.15038895 
times higher than the remaining mitochondrial DNA (Walberg and Clayton, 1981; Aquadro and Greenberg, 1983; Cann et al., 1984). Several studies on the phylogeny and evolution of the Equus genus using the D-loop region of mtDNA have been conducted (Kim et al., 1999; Ivankovic et al., 2002; Cothran et al., 2005; Kakoi et al., 2007; Bower et al., 2013). This makes the D-loop region a preferred choice for DNA diversity and phylogenetic analyses in horses and donkeys. The aim of this study was to develop a fast and easy method to differentiate the maternal origin of mules and hinnies, using D-loop region polymorphisms amplified by multiplex-PCR.

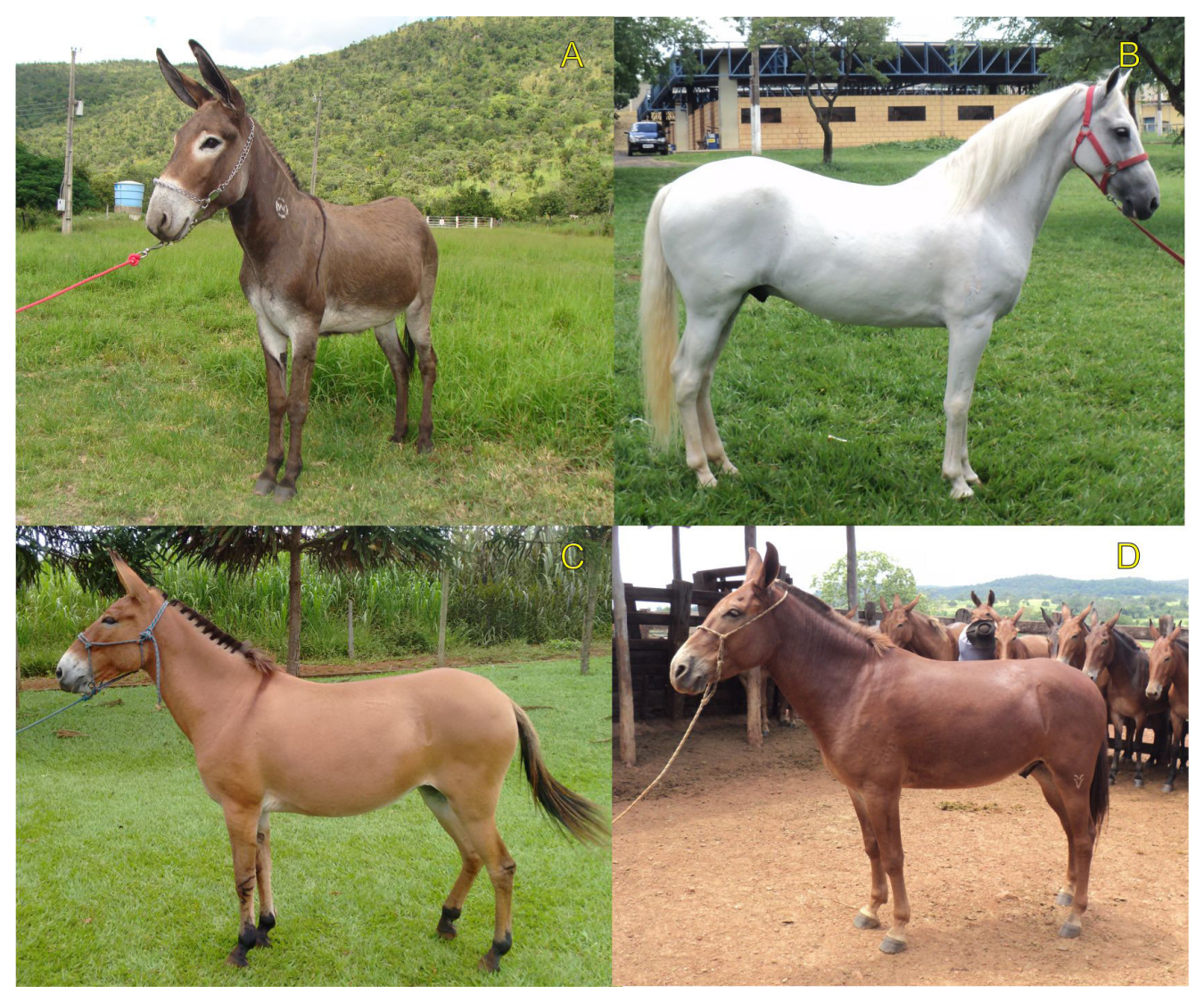

Figure 1. Pictures of representative equids. A. Donkey (Pêga); B. horse (Mangalarga Marchador); C. mule; D. hinny.

\section{MATERIAL AND METHODS}

The blood samples of the 77 animals analyzed in this study (17 horses, 32 donkeys, 18 mules, and 10 hinnies) were provided by Brazilian ranchers and the Brazilian Platform of Genetic Resources (Table 1). 


\begin{tabular}{|c|c|c|c|c|}
\hline Species & Total No. & Number & Breed & Origin \\
\hline \multirow{10}{*}{ Horse } & 17 & 1 & Arabian $^{2}$ & \multirow{10}{*}{ Federal District, Brazil } \\
\hline & & 2 & Baixadeiro $^{1,2}$ & \\
\hline & & 2 & Breton $^{2}$ & \\
\hline & & 2 & Campeiro 1,2 & \\
\hline & & 2 & Campolina ${ }^{1,2}$ & \\
\hline & & 2 & Crioulo $^{1,2}$ & \\
\hline & & 2 & Lavradeiro $^{1,2}$ & \\
\hline & & 1 & Mangalarga Marchador ${ }^{1,2}$ & \\
\hline & & 2 & Marajoara $^{1,2}$ & \\
\hline & & 1 & Pantaneiro $^{1,2}$ & \\
\hline \multirow[t]{3}{*}{ Donkey } & 32 & 19 & Pêga $^{1,2}$ & Minas Gerais State and Federal District, Brazil \\
\hline & & 9 & Brasileiro ${ }^{1,2}$ & Federal District, Brazil \\
\hline & & 4 & Nordestino $^{1,2}$ & Northeast and Federal Districts, Brazil \\
\hline Mule & 18 & 18 & Pêga donkey x Mangalarga Marchador horse & Minas Gerais State, Brazil \\
\hline Hinny & 10 & 10 & Mangalarga Marchador horse x Pêga donkey & Minas Gerais State, Brazil \\
\hline Total & 77 & & & \\
\hline
\end{tabular}

${ }^{1}$ Brazilian locally adapted breeds. ${ }^{2}$ Samples provided by the Brazilian Platform of Genetic Resources - Brazilian Agricultural Research Corporation - National Center for Genetic Resources and Biotechnology, Brasília, Brazil.

Animals were handled according to Brazilian legislation and the experiment was approved by the Ethics Committee of the Federal University of Uberlândia, Brazil (protocol No. 160/13). The hybrids were primarily scored as mule or hinny based on their breeding records as provided by their owners. The blood samples were sent to the laboratory as blind samples, so the specialist who did the polymerase chain reaction (PCR) genotyping was unaware of the animals' identity and breed. Genomic DNA was extracted from the blood using the DNeasy Blood \& Tissue Kit (Qiagen, Hilden, Germany). We used 50 ng genomic DNA in $20 \mu \mathrm{L}$ PCR mix ( 1 U Taq DNA polymerase, $800 \mu \mathrm{M}$ dNTP mix, $1.25 \mathrm{mM} \mathrm{MgCl}{ }_{2}$, and 7.5 pmol each primer), using the following conditions: $95^{\circ} \mathrm{C}$ for $3 \mathrm{~min} ; 36$ cycles of $95^{\circ} \mathrm{C}$ for $30 \mathrm{~s}, 65^{\circ} \mathrm{C}$ for $30 \mathrm{~s}$, and $72^{\circ} \mathrm{C}$ for $1 \mathrm{~min}$; followed by $72^{\circ} \mathrm{C}$ for $10 \mathrm{~min}$. The forward primer was designed to hybridize with a conservative region of mtDNA D-loop of horse and donkey (5'-CTGGCATCTGGTTCTTTCTT-3'). The reverse primers were designed to hybridize a polymorphic region of D-loop in horse (5'-GGTTTGGCAAGATTGTGTTG-3') and donkey (5'-GTGTGTGAGAGTTAGGCTTC-3'), amplifying two specific fragments of 620 and $689 \mathrm{bp}$, respectively, in a multiplex-PCR. The position of each primer in the hyper-variable mtDNA D-Loop region is highlighted in Figure S1. The fragments were resolved on a $1.8 \%$ agarose gel. One sample of the mule D-loop amplicon (620 bp), and one of the hinny amplicon (689 bp) were purified from the agarose gel using the Wizard ${ }^{\circledR}$ SV Gel and PCR Clean-Up System (Promega, Madison, USA) and sequenced by Sanger method in a DNA sequencing facility (Helixxa Serviços Genômicos, Brazil). These sequences were submitted to GenBank (accession Nos. KU881746.1 and KU881747.1). The resulting sequences were aligned against GenBank reference sequences (E. caballus: NC_001640.1; E. asinus: X97337.1) using the internet based Clustal Omega software (EMBL-EBI, UK).

\section{RESULTS AND DISCUSSION}

All genotyped animals (donkeys, horses, hinnies, and mules) presented D-loop amplicons of the expected size in 100\% accordance with their breeding records (Figure 2). To confirm the PCR genotyping and amplicon identity, one amplicon from a hinny and one from 
a mule were sent for DNA sequencing. The alignment of the amplicons' sequences against the GenBank references confirmed their identity (Figure 3A and B), as well as indicating the hyper-variable 3'-region of D-loop, which confers specificity for this multiplex-PCR genotyping method (Figure 3C and D).

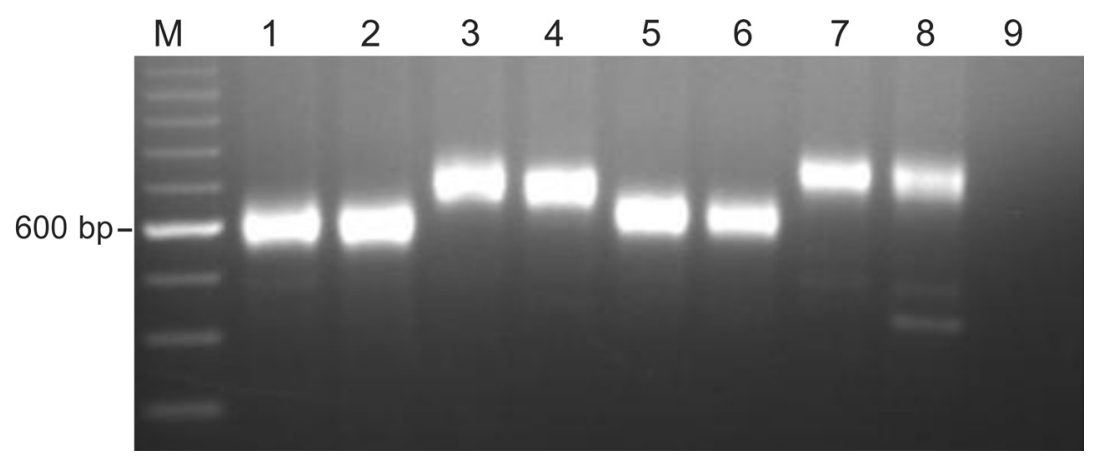

Figure 2. Agarose gel electrophoresis of multiplex-PCR amplicons from eight representative animals. Lane $M=$ Molecular marker; 100-bp ladder (Invitrogen). mtDNA D-loop amplicons: horse (lanes 1 and 2); donkey (lanes 3 and 4); mule (lanes 5 and 6 ); hinny (lanes 7 and 8); and PCR negative control (lane 9).

A

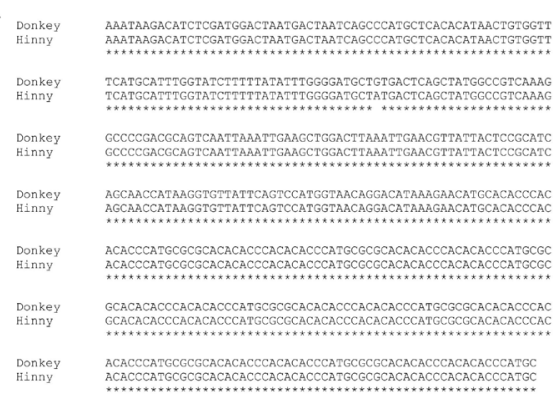

$\mathrm{C}$

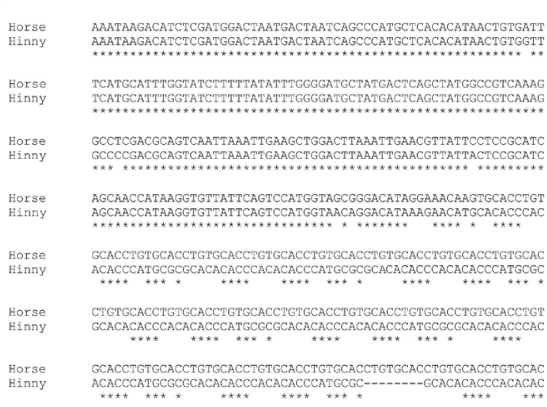

AaCGTPATTCCTCCGCAR

Herse
Hi DnY

Horse
Hinny

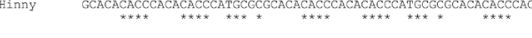

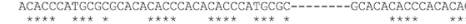

B

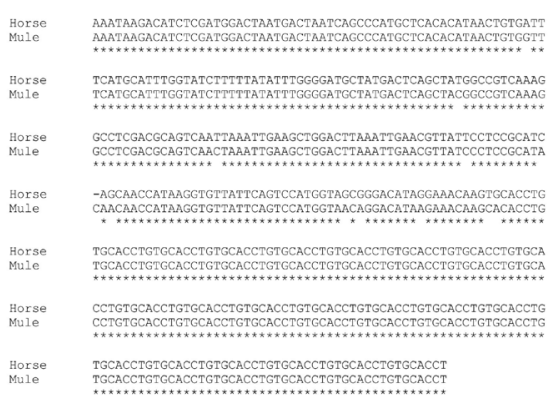

$\mathrm{D}$

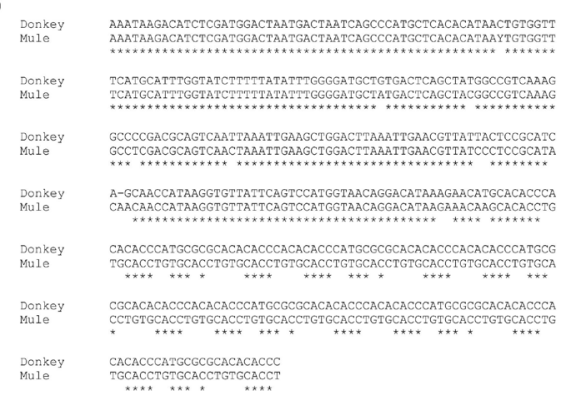

Figure 3. Alignment of mtDNA D-loop sequences. A. Donkey x hinny; B. horse x mule; C. horse x hinny; and D. donkey x mule. GenBank accession Nos.: donkey (X97337.1), horse (NC_001640.1), hinny (KU881746.1), and mule (KU881747.1). The asterisks represent conserved nucleotide identity between sequences.

Genetics and Molecular Research 15 (3): gmr.15038895 
A methodology for genotyping horse, donkey, and their hybrids has been presented in a previous study (Zhao et al., 2005). In the study of Zhao et al. (2005), two DpnII restriction sites were primer-induced in polymorphic regions of the nuclear gene Protamine P1, and mitochondrial Cytochrome b; both of which contain natural polymorphic DpnII sites only in horse sequences. In this PCR-RFLP strategy, the horse's Protamine P1 and Cytochrome $b$ amplicons are cut twice by DpnII, and the donkey's amplicons are cut only once in each gene. The final resulting visible DNA band pattern (two for horse and donkey, and three for their hybrids) permits genotyping of the animals. On the other hand, the genotyping method suggested here is based on a single-PCR of a single-target mtDNA sequence (D-loop), using three primers. In addition, there is no need for further restriction enzyme digestion, which makes our process faster and cheaper. Our method only permits us to identify the maternal origin of the hybrids, differentiating mules from hinnies. However, the phenotypic (visual) differentiation of mules from horses and hinnies from donkeys is not a problem for breeders and ranchers (Benirschke et al., 1964), according to our field experience. Therefore, the pivotal problem is to distinguish mules from hinnies and for this the method presented in this study is very effective.

We believe that the new methodology presented here will permit a fast, cheap, and easy way to differentiate hinnies and mules with accuracy. This method can help breeders, ranchers, horse associations, animal science professionals, and researchers to manage their equid herds and pedigree registers with more confidence and precision.

\section{Conflicts of interest}

The authors declare no conflict of interest.

\section{ACKNOWLEDGMENTS}

We thank breeders, ranchers, and The Brazilian Platform of Genetic Resources for providing the biological samples used in this study. Research supported by Coordenação de Aperfeiçoamento de Pessoal de Nível Superior (CAPES), Brazil, Conselho Nacional de Desenvolvimento Científico e Tecnológico (CNPq), Brazil, and Embrapa Genetic Resources and Biotechnology, Brazil.

\section{REFERENCES}

Allen WR and Short RV (1997). Interspecific and extraspecific pregnancies in equids: anything goes. J. Hered. 88: $384-$ 392. http://dx.doi.org/10.1093/oxfordjournals.jhered.a023123

Aquadro CF and Greenberg BD (1983). Human mitochondrial DNA variation and evolution: analysis of nucleotide sequences from seven individuals. Genetics 103: 287-312.

Aranguren-Méndez J, Gómez M and Jordana J (2002). Hierarchical analysis of genetic structure in Spanish donkey breeds using microsatellite markers. Heredity 89: 207-211. http://dx.doi.org/10.1038/sj.hdy.6800117

Beja-Pereira A, England PR, Ferrand N, Jordan S, et al. (2004). African origins of the domestic donkey. Science 304: 1781. http://dx.doi.org/10.1126/science. 1096008

Benirschke K, Low RJ, Sullivan MM and Carter RM (1964). Chromosome study of an alleged fertile mare mule. J. Hered. 55: 31-38.

Bower MA, Whitten M, Nisbet RE, Spencer M, et al. (2013). Thoroughbred racehorse mitochondrial DNA demonstrates closer than expected links between maternal genetic history and pedigree records. J. Anim. Breed. Genet. 130: 227235. http://dx.doi.org/10.1111/j.1439-0388.2012.01018.x

Genetics and Molecular Research 15 (3): gmr.15038895 
Brown WM, George Jr M and Wilson AC (1979). Rapid evolution of animal mitochondrial DNA. Proc. Natl. Acad. Sci. USA 76: 1967-1971. http://dx.doi.org/10.1073/pnas.76.4.1967

Cann RL, Brown WM and Wilson AC (1984). Polymorphic sites and the mechanism of evolution in human mitochondrial DNA. Genetics 106: 479-499.

Chen JX, Sun YJ, Manglai D, Min LJ, et al. (2010). Maternal genetic diversity and population structure of four Chinese donkey breeds. Livest. Sci. 131: 272-280. http://dx.doi.org/10.1016/j.livsci.2010.04.012

Cothran EG, Juras R and Macijauskiene V (2005). Mitochondrial DNA D-loop sequence variation among 5 maternal lines of the Zemaitukai horse breed. Genet. Mol. Biol. 28: 677-681. http://dx.doi.org/10.1590/S1415-47572005000500006

Ivankovic A, Kavar T, Caput P, Mioc B, et al. (2002). Genetic diversity of three donkey populations in the Croatian coastal region. Anim. Genet. 33: 169-177. http://dx.doi.org/10.1046/j.1365-2052.2002.00879.x

Jansen T, Forster P, Levine MA, Oelke H, et al. (2002). Mitochondrial DNA and the origins of the domestic horse. Proc. Natl. Acad. Sci. USA 99: 10905-10910. http://dx.doi.org/10.1073/pnas.152330099

Kakoi H, Tozaki T and Gawahara H (2007). Molecular analysis using mitochondrial DNA and microsatellites to infer the formation process of Japanese native horse populations. Biochem. Genet. 45: 375-395. http://dx.doi.org/10.1007/ $\underline{\text { s10528-007-9083-0 }}$

Kim KI, Yang YH, Lee SS, Park C, et al. (1999). Phylogenetic relationships of Cheju horses to other horse breeds as determined by mtDNA D-loop sequence polymorphism. Anim. Genet. 30: 102-108. http://dx.doi.org/10.1046/j.13652052.1999.00419.x

Rong R, Chandley AC, Song J, McBeath S, et al. (1988). A fertile mule and hinny in China. Cytogenet. Cell Genet. 47: 134-139. http://dx.doi.org/10.1159/000132531

Rossel S, Marshall F, Peters J, Pilgram T, et al. (2008). Domestication of the donkey: timing, processes, and indicators. Proc. Natl. Acad. Sci. USA 105: 3715-3720. http://dx.doi.org/10.1073/pnas.0709692105

Ryder OA, Chemnick LG, Bowling AT and Benirschke K (1985). Male mule foal qualifies as the offspring of a female mule and jack donkey. J. Hered. 76: 379-381.

Short RV (1975). The contribution of the mule to scientific thought. J. Reprod. Fertil. Suppl. 23: 359-364.

Short RV (1997). An introduction to mammalian interspecific hybrids. J. Hered. 88: 355-357. http://dx.doi.org/10.1093/ oxfordjournals.jhered.a023117

Walberg MW and Clayton DA (1981). Sequence and properties of the human KB cell and mouse L cell D-loop regions of mitochondrial DNA. Nucleic Acids Res. 9: 5411-5421. http://dx.doi.org/10.1093/nar/9.20.5411

Zhao CJ, Han GC, Qin YH and Wu Ch (2005). Differentiating among horse (Equus caballus), donkey (Equus asinus) and their hybrids with combined analysis of nuclear and mitochondrial gene polymorphism. J. Anim. Breed. Genet. 122: 285-288. http://dx.doi.org/10.1111/j.1439-0388.2005.00535.x

\section{Supplementary material}

Figure S1. Equus asinus and Equus caballus complete mitochondrial genome sequence with the D-loop region (highlighted in yellow) and primer sequences used in this study (forward primer highlighted in gray and reverse primers highlighted in red and green for donkey and horse, respectively).

Genetics and Molecular Research 15 (3): gmr.15038895 